\title{
ASSESSMENT OF OPERATIONAL PERFORMANCE OF PUBLIC SECTOR FUNDED INFRASTRUCTURE IN NIGERIA: THE AIRPORTS PERSPECTIVE
}

\author{
Ikechukwu A. Diugwu \\ Federal University of Technology, Minna, Nigeria \\ E-mail: i.diugwu@futminna.edu.ng \\ Obioma R. Nwaogbe \\ Federal University of Technology, Minna, Nigeria \\ E-mail: obioma.nwaogbe@futminna.edu.ng \\ Victor Omoke \\ Federal University of Technology, Minna, Nigeria \\ E-mail: victor.omoke@futminna.edu.ng \\ Solomon T. Johnson \\ Federal University of Technology, Minna, Nigeria \\ E-mail: Solomon.johnson@st.futminna.edu.ng \\ Ashem E. Egila \\ Federal University of Technology, Minna, Nigeria \\ E-mail: egilashem@gmail.com
}

Submission: $18 / 04 / 2018$ Revision: 02/05/2018 Accept: 14/05/2018

\section{ABSTRACT}

The study assessed the performance of public sector funded infrastructure in Nigeria, with a special focus on airports. It utilized secondary data obtained from the Federal Airports Authority of Nigeria (FAAN), the Nigerian Civil Aviation Authority (NCAA), and the National Bureau of Statistics (NBS) covering the period 2004 to 2016. A simple regression analyses of the data were carried out using total number of employees as the predictor variable and the total aircraft movement, total passenger movement, and total cargo movement as the dependent variables. 
The results of the analyses show that the $p$ values calculated were $<0.05$ alpha value, implying existence of a statistical relationship among the dependent variables (aircraft movement, passenger throughput, and cargo throughput) and independent variable (number of employees). Furthermore, the time series graphs show fluctuations in growth of the outputs (passenger throughput, aircraft movement and cargo throughput) for the Nigerian air transport system at various periods. This study has shown that there is a need for the government and stakeholders to take immediate actions in tackling factors responsible for the decline and fluctuations in the air transport industry.

Keywords: air transport; passenger throughput; aircraft movement; operational performance; infrastructure

\section{INTRODUCTION}

"Measurement is the first step that leads to control and eventually to improvement. If you can't measure something, you can't understand it. If you can't understand it, you can't control it. If you can't control it, you can't improve it."

\section{- H. James Harrington}

The transport sector is noted to be critical for development; transport investment promotes access and contributes to economic growth and quality of life, while inadequate transport sector performance constrains development, aggravates the conditions of the poor, harms the environment, ignores the changing needs of users and exceeds the capacity of public finances (WORLD BANK, 1996).

There are benefits derivable from adequate investment in the transport sector. For instance, WORLD BANK (1996) projected an economic rate of return of about $22 \%$ on transport projects upon completion, a lowered agricultural production costs due to increased access to markets and credit, an indirect facilitation of the development of the non-agricultural rural economy, increased labor market efficiency and access to amenities, as well as domestic and international trade through a more efficient movement of people and freight . 
The importance of the transport sector to economic development is further noted by Owen (1987), who argues that mobility is about the most important contributor to economic and social progress because the other components of a satisfactory life (ranging from food and health to education and employment) rely on the availability of adequate means of movement of people, goods and ideas. This notion finds strong support in Easterly and Rebelo (1993), whose work established that investment in public infrastructure in transport has a significant and positive effect on economic growth.

There are also country specific studies, for instance, Dharmawan (2012), that highlight the relationship between provision of adequate (air) transport infrastructure and economic performance. A similar relationship between investment in transport infrastructure and economic growth is equally observed in Nigeria. For instance, the study by Bosede et al. (2013) concluded that investments in transport infrastructure contributed positively to growth, with a strong and statistically significant impact. The outcome of this study has necessitated arguments in favour of economic policies that would not only improve the transport infrastructure, but also increase the investments in the sector with a view to achieving a sustainable economic growth in Nigeria.

These possible benefits notwithstanding, it has been observed that the contribution of the transport sector to Nigeria's GDP has been dwindling. This is in spite of the enormous expenditure by the Government aimed at promoting viable sustainable transportation system Consequently, studies, for instance by Anfofum et al. (2015), have recommended a proactive and dynamic cohesive transport policy that would be beneficial to all stakeholders as a solution.

Therefore, there is a need to periodically assess a nation's transport policy with a view to making it more efficient and effective. This entails an efficient use of the sector's resources as well as a proper maintenance of the assets, because "public transport systems that fall into disrepair because they are economically or financially unsustainable, fail to serve the needs of the poor, and often have environmentally damaging consequences" (World Bank, 1996).

A failure to periodically review a nation's transport policy framework leads to a possible stagnation in the expansion of transport physical infrastructure; because a 
rapid growth in transport demand strains the transport capacity, leading to capacity crisis, increase in congestion, and other challenges (UGBOAJA, 2013). Based on the observations by Pabedinskaite and Akstinaitè (2014), the development of a proactive and cohesive transport policy in Nigeria can best be achieved through an assessment of the operational efficiency and the quality of the services provided by the sectors and its sub-sectors.

Transport infrastructure connotes different thins to different people. Consequently, this study adopts the description of transport infrastructure by Crockatt (2000) as encompassing air infrastructure among others, as well as the definition of air transport infrastructure as the facilities and oversight required to provide efficient and on-time air transport services to the public (JUAN, 1995).

The aviation industry has been chosen because of its strategic role in the attainment of sustainable development. It has been observed that improvement in the air transport infrastructure (encompassing airports and air-traffic management), lowers transport costs, supports rapid economic growth and increases personal mobility, thus plays a key role as a facilitator of, and good complement to policies aimed at improving living standards and poverty alleviation (OXFORD ECONOMIC FORECASTING, 2003).

Earlier studies, for instance by Ishutkina and Hansman (2008), found a positive relationship between air transport and economic development. Again, the study by Baltaci et al. (2015) supports the view of airline transport as being an important factor that positively affects economic growth such and that an economic growth could be achieved by increasing the number of active airports and traffic frequency.

It is within the above context that this paper attempts to assess the operational performance of airports in Nigeria. This, it is hoped, would lead to the (re) establishment of clearly defined responsibilities and objectives of the various stakeholders within the sector, improved control by administrators, management and regulators, a strategic alignment of objectives, as well as a better understanding of the business processes in the sector (KAYDOS, 1998). 
DOI: $10.14807 /$ ijmp.v10i1.828

\section{LITERATURE REVIEW}

In view of the level of competition in global business environment, there is a need for targeted cost-effective timely investment, as well as the development and implementation of policies that would lead to successful economic development (JUAN, 1995). To achieve this, management principles (e.g. total quality management) are used to assess operational performance, that would form the basis for the development of plan(s) capable of enhancing customer satisfaction through continuous improvements in quality of products, services and processes.

It has been proven that the adoption of these management philosophies or principles lead to improvements in various aspects of a business endeavor such as competitiveness, the ability to satisfy the requirements of customers, effectiveness, flexibility, and competitiveness of business organizations (OAKLAND, 1995; OAKLAND, 2003; TERZIOVSKI, 2006). The application of total quality management principles to services oriented organizations such as airports has been discussed in Bon and Mustafa (2013).

According to the United States Federal Aviation Administration, "an airport is defined in the law as any area of land or water used or intended for landing or takeoff of aircraft including appurtenant area used or intended for airport buildings, facilities, as well as rights of way together with the buildings and facilities." An inference from Gillen and Lall (2001), is that an airport is a complex and highly sophisticated system, made up of an air system comprising of two major elements, the airside and landside.

The basic functions of an airport are to provide access for aircraft to the national airspace, permit easy interchange between aircrafts, and facilitate the consolidation of traffic. To effectively deliver these functions, an airport must have some basic infrastructure elements such as runway, taxiways, aprons (airside infrastructure) and airport ground resources for passengers or cargo. Airport infrastructure could be seen as an aggregate of different services (airside, landside, security and safety, as well as surface) offered in an airport (JUAN, 1995).

Airside services include the airfield, gates, jet-ways, all facilities associated with the movement of aircraft, as well as all facilities beyond the passenger security areas such as runways, taxiways, aprons whereas the landside services encompass 
INDEPENDENT JOURNAL OF MANAGEMENT \& PRODUCTION (IJM\&P)

http://www.ijmp.jor.br

v. 10, n. 1, January - February 2019

ISSN: 2236-269X

DOI: 10.14807/ijmp.v10i1.828

all facilities associated with the movement of passengers and baggage to or from aircraft, facilities devoted to service passengers into and inside the terminal areas such as passenger services, food and beverage concessions, duty free, car parking (JUAN, 1995; JUAN, 2001).

Furthermore, security and safety services include facilities that are associated with the provision of police, security, customs, immigration, fire and rescue, while surface access refers to road and rail (JUAN, 1995; JUAN, 2001). Among the concerns of airport industry is how these services are performed; as such, routine measurement of productivity becomes important.

Earlier studies established a positive relation between availability of infrastructure and level of economic performance. With specific reference to the transport sector, a study on the implication of improvement in transport infrastructure and economic growth by Bosede et al. (2013) recommended an increase in the budgetary allocation to the transport sector as a way of improving infrastructure availability. Hence, there is a need to ensure that allocated funds are judiciously spent.

Many studies (JARŽEMSKIENĖ, 2012; ZHANG et al., 2012; TSENG et al., 2008) have been carried out on the operational performance of airports with a view to assessing their efficiency, productivity, rate of development, as well as capacity utilization. For instance, a study by Pius et al. (2017a) assessed the operational performance of Murtala Muhammed International Airport (MMIA) terminal in Lagos and established a statistically significant relationship between aircraft movement and variables such as total cost, total assets, wages, and number of employees of the airport.

Another study by Wanke et al. (2016) on the productive efficiency of Nigerian airports using Fuzzy-DEA identified airport fixed costs (capacity cost) as an efficiency driver and suggested the adoption of an airport efficiency improvement policy based on keeping capacity (fixed) costs under control.

Airport performance assessment is carried out for reasons such as attraction of investments, reduction of operational cost, improvement of efficiency, monitoring of safety and environmental impact among others (DOGANIS, 2005). Most airports aim to maximize the movement of aircrafts, while increasing efficiency level in their 
operations processes as a way of achieving sustainable competitive edge over their competitors in the sector.

Stephens and Ukpere (2011) note that air transport is relatively expensive when compared with other modes of transport like road, rail and water transportation, and competent and motivated human resources are needed for effective and efficient utilization of physical infrastructure within the airports. Therefore, the availability of human resources and its capabilities becomes crucial in any performance assessment.

To this end, some studies, for instance, Sutia et al. (2013) have been carried out to investigate the influence of influence of investment in human capital on airport performance. The provision of airport infrastructure is capital intensive and requires long gestation periods to generate returns and breakeven.

Indeed, existing literature has suggested that airports that are effectively regulated and subjected to good performance controls would invariably have efficient terminals capable of earning higher profits and/or further investments (NWAOGBE et al., 2017a; OGWUDE et al., 2018; PIUS et al., 2017b; NWAOGBE et al., 2017b).

Infarct, a study by Ahmad and Schroeder (2003) empirically showed that as human resource management system deviates from the ideal-type human resource management system, the plant's performance decreases, and this relationship is statistically significant.

A study of the operational efficiency of major airports in the United States carried out by Sarkis (2000) was based on four resource input measures including airport operational costs, number of airport employees, gates and runways, and five output measures including operational revenue, passenger flow, commercial and general aviation movement, and total cargo transportation.

\section{RESEARCH METHODOLOGY}

\subsection{Study Area}

This study covers air transportation in Nigeria for both domestic travel and international travel. Nigeria is a country occupying 923,768.64 square Kilometres, situated on the West Coast of Africa and lies on latitudes $4^{\circ}$ North of the Equator and latitudes $3^{\circ}$ and $14^{\circ}$ on the East of the Greenwich Meridian. It shares boundaries 
INDEPENDENT JOURNAL OF MANAGEMENT \& PRODUCTION (IJM\&P)

http://www.ijmp.jor.br

v. 10, n. 1, January - February 2019

ISSN: 2236-269X

DOI: $10.14807 /$ ijmp.v10i1.828

with The Republics of Benin and Niger in the West, Cameroon in the East, Niger and Chad in the North and the Gulf of Guinea in the South (NIGERIAN NATIONAL PETROLEUM CORPORATION, 2016).

It has nine (9) international airports, the major ones being Murtala Muhammad Airport, Lagos, Nnamdi Azikwe Airport, Abuja and Malam Aminu Kano Airport, Kano. The Murtala Muhammed Airport is the hub and very busy, accounting for about $80 \%$ of the total air transportation operation services in Nigeria. The Federal Airport Authority, Nigeria Civil Aviation Authority and the Nigeria Airspace Management Agency, have more than 24 local airports, some international airports also function as local airport.

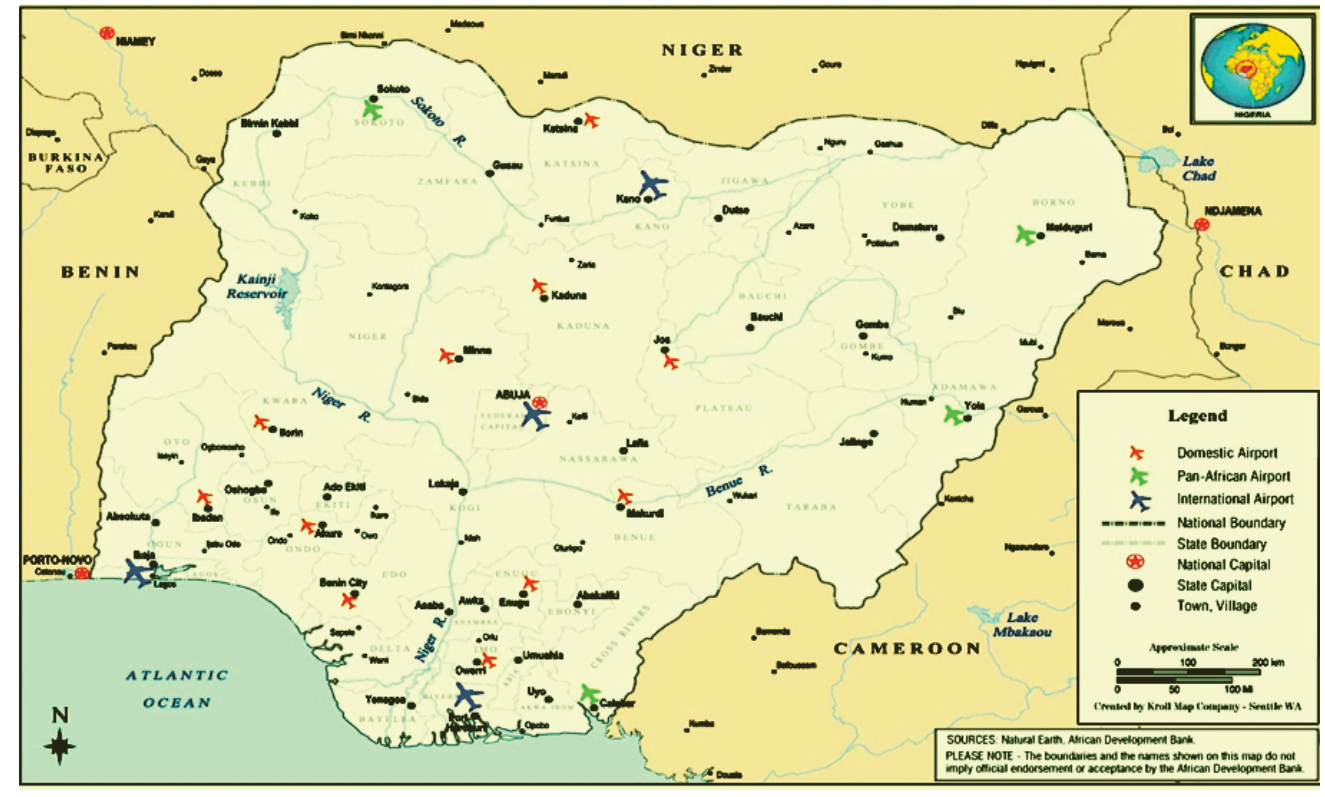

Figure 1: Map showing some airports in Nigeria

\subsection{Formulation of Hypothesis}

The following hypothesis are proposed to facilitate data collected to arrive at a specified conclusion, they are:

- $\mathbf{H}_{1}$ : There is a significant relationship between number of employee and aircraft throughput.

- $\mathbf{H}_{\mathbf{2}}$ : There is a significant relationship between number of employee and passenger throughput.

- $\mathbf{H}_{3}$ : There is a significant relationship between number of employee and cargo throughput. 
INDEPENDENT JOURNAL OF MANAGEMENT \& PRODUCTION (IJM\&P)

http://www.ijmp.jor.br

v. 10, n. 1, January - February 2019

ISSN: 2236-269X

DOI: $10.14807 /$ ijmp.v10i1.828

\subsection{Choice of Method}

A determination of whether there is a significant linear relationship between the specified independent variable $X$, and a dependent variable $Y$ as indicated in the proposed hypothesis, would focus on the slope of a regression line. Thus the decision to use regression analysis for this study. In situations where there is only one independent or explanatory variable (as in this case), Salvatore and Reagle (2002), observe that a simple regression analysis is carried out. The suitability of regression analysis for this study is shown variously in Aczel and Sounderpandian (2009), Rencher (2003), Weiss (2012).

\subsection{Source of Data and Analysis Software}

This study utilised secondary data (2004-2016) from the Federal Airports Authority of Nigeria (FAAN), Nigerian Civil Aviation Authority (NCAA), and the National Bureau of Statistics (NBS). Statistical Package for the Social Sciences (SPSS) was used for the linear regression analysis, while Minitab Statistical Software was for was used for data presentation, graphical of time series. Table 1 shows the data used in the analysis.

Table 1: Cumulative Data of Nigeria air transport operation Statistical Data

\begin{tabular}{|c|c|c|c|}
\hline YEAR & $\begin{array}{c}\text { TOTAL PASSENGER } \\
\text { MOVEMENT } \\
(\text { MILLION) }\end{array}$ & $\begin{array}{c}\text { TOTAL CARGO } \\
\text { MOVEMENT (KG) }\end{array}$ & $\begin{array}{c}\text { TOTALNUMBER } \\
\text { OF EMPLOYEES } \\
\text { (THOUSAND) }\end{array}$ \\
\hline 2004 & $8,157,152$ & $99,411,126$ & 25,004 \\
\hline 2005 & $8,310,515$ & $77,286,904$ & 24,689 \\
\hline 2006 & $8,208,195$ & $93,248,313$ & 24,375 \\
\hline 2007 & $8,409,944$ & $94,523,909$ & 23,246 \\
\hline 2008 & $8,723,864$ & $99,831,668$ & 23,748 \\
\hline 2009 & $12,526,464$ & $166,782,990$ & 23,432 \\
\hline 2010 & $13,981,677$ & $180,836,476$ & 23,117 \\
\hline 2011 & $14,889,820$ & $175,809,524$ & 22,803 \\
\hline 2012 & $14,116,790$ & $182,804,328$ & 20,177 \\
\hline 2013 & $15,274,833$ & $198,443,781$ & 21,321 \\
\hline 2014 & $15,722,423$ & $201,208,117$ & 21,453 \\
\hline 2015 & $15,092,478$ & $211,324,605$ & 22,112 \\
\hline 2016 & $14,562,191$ & $165,568,809$ & 22,301 \\
\hline
\end{tabular}

\subsection{Development of Regression Model and EquationIntroduction}

The simple linear regression, is a type of regression in which a single numerical independent variable, $X$, is used to predict the numerical dependent variable $Y$. It is observed from sources such as (RENCHER, 2003; WEISS, 2012; ANDERSON et al., 2015; TABACHNICK; FIDELL, 2013; ACZEL; SOUNDERPANDIAN, 2009) that a general simple regression model, assuming a 
linear relationship between the dependent variable and the independent variable, takes the form:

$Y=\beta_{0}+\beta_{1} X_{1}+\epsilon$

Where,

\author{
$Y$ is the dependent variable \\ $X_{I}$ is the independent variable or predictor \\ $\beta_{0}$ is the $\mathrm{Y}$ intercept \\ $\beta_{1}$ is the slpoe \\ $E$ (the error term) is a random variable
}

Berenson et al. (2012) note that the $Y=\beta_{0}+\beta_{1} X_{1}$ portion of a simple regression equation is a straight line, with the slope of the line $\left(\beta_{1}\right)$, respresenting the expected change in $Y$ per unit change in $X$, and the intercept $\left(\beta_{0}\right)$, representing the mean value of $Y$ when $X$ equals 0 . The overlying assumptions used here have ben explained in great details (ANDERSON et al., 2015; KELLER, 2014; RENCHER, 2003).

The error term, $\epsilon$, is assumed to be normally distributed with a mean of zero and standard deviation $(\sigma)$ and is independent of the error terms associated with all other observations associated with all other observations. Again, the probability of the error distribution is normal, while the randomness in the dependent variable (y) comes from the error term $(\epsilon)$.

A total number of seven variables were selected and used for this study. The dependent (response) variables are total aircraft movement (TAM), total passenger movement (TPM), and total cargo movement (TCM), while the independent (predictor) variable is total number of employees (TNE).

The TAM describes the total number of aircraft arriving or departing the airports (including international and domestic traffic from both commercial and private airlines). An aircraft that arrives once and departs once is recorded as two movements.

The TPM is the number of passengers arriving or departing over a period of one year, excluding those passengers who are just transiting from the airport. A passenger that made a round trip journey is counted as two origination and Destination (O\&D) passenger. 
The TCM describes the annual record of cargo loaded or unloaded at the airport. The TNE is the total number of staff (strategic, tactical, and the operational level), working at the airport at a given time.

\subsection{The Coefficient of Determination $\left(r^{2}\right)$ and Adjusted Coefficient of Determination}

According to Keller (2014), there are several models that can be used to assess regression models. This study shall use coefficient of determination $\left(r^{2}\right)$, Ttest and the F-test analyses shall be used as a measure of goodness of fit and significance. The coefficient of determination $\left(r^{2}\right)$ measures the proportion of the variation in the dependent variable that is explained by the combination of the independent variables in the regression model (ACZEL; SOUNDERPANDIAN, 2009; SALVATORE; REAGLE, 2002). The coefficient of determination can be determined using equation (4) below (ACZEL; SOUNDERPANDIAN, 2009; NEWBOLD et al., 2013);

$$
\begin{aligned}
& r^{2}=\frac{\text { Regression Sum of Squares (RSS) }}{\text { Total sum of squares (TSS) }} \\
& \text { But, } \\
& \text { SST }=\text { RSS }+ \text { Error Sum of Squares (ESS) }
\end{aligned}
$$

Making RSS the subject in equation (3), substituting into equation (3) above and solving, we have;

$$
r^{2}=\frac{R S S}{T S S}=\frac{T S S-S S E}{T S S}=1-\frac{E S S}{T S S}
$$

R-square always lies between 0 and 1 , with literature suggesting that a value of $r^{2}$ close to 0 implies that the estimated regression equation explains none of the variation in $\mathrm{Y}$, while an $r^{2}$ close to 1 implies that all points lie on the regression line (SALVATORE; REAGLE, 2002; ACZEL; SOUNDERPANDIAN, 2009; WEISS, 2012).

The coefficient of determination $\left(r^{2}\right)$ measures the rate of variation in the dependent variable, explained by the independent variable. The coefficient has a result between zero and one ( 0 and 1 ), with a value of (1) demonstrating a great fit. The values are changed to percentage, to find out the strength of relationship compared with the significance level between the variables. The decision rule here 
states that if $r^{2} \geq 50 \%$, the relationship is strong; But if $r^{2}<50 \%$, then relationship is weak.

In order to establish if a significant relationship exists between the dependent variable and the independent variable(s), the F-test would be used to test for overall significance. Where an overall significance exists, a t-test, which tests for individual significance, would be used to ascertain if each of the individual independent variables is significant (ANDERSON et al., 2015; ACZEL; SOUNDERPANDIAN, 2009).

The implication of rejecting $\mathrm{H}_{0}$ is that there is sufficient evidence, statistically, to conclude that one or more of the parameters is not equal to zero and that the overall relationship between the dependent variable and the independent variable is significant However, if $\mathrm{H}_{0}$ cannot be rejected, then there is no sufficient evidence to conclude that a significant relationship is present.

Recall from equation (1) above that the regression model proposed for this study is $y=\beta_{0}+\beta_{1} x_{1}$. Therefore, the hypotheses for the F-Test involve the parameters of the regression model, thus:

$$
H_{0}=\beta_{0}=\beta_{1}=0
$$

The decision rule for F-Test for overall significance is to reject $\mathrm{H}_{0}$ if $p$-value $\leq \propto$ or $F \geq F_{\propto \propto}$. $F_{\propto \propto}$ is based on an $\mathrm{F}$ distribution having $\mathrm{p}$ degrees of freedom in the numerator and n-p-1 degrees of freedom in the denominator.

$$
F=\frac{M S R}{M S E}
$$

where MSR is mean square due to regression and MSE is mean square due to error.

Rejecting $\mathrm{H}_{0}$ signifies that a sufficient statistical evidence to conclude that one or more of the parameters chosen is not equal to zero exists.

The decision rule for t-Test for individual significance is to reject $\mathrm{H}_{0}$ : if $p-$ value $\leq \propto$; or $t \leq-t_{\propto \alpha / 2}$; or if $t \geq t_{\propto / 2}$.

There are however observations that the values of $r$-squared are affected by the inclusion of unnecessary independent variable. In this situation, it is recommended that a modified version of r-squared, the adjusted r-squared. which has been adjusted for the number of predictors in the model be used. The adjusted $r$ squared can only increase if the new term improves the model more than would be 
expected by chance, and decreases when a predictor improves the model by less than expected by chance (MINITAB BLOG EDITOR, 2013)

\section{DATA ANALYSIS AND DISCUSSION}

\subsection{Descriptive Statistics}

Table 2 shows the descriptive statistics of the data used. The values of the mean and standard deviation show that the data are original.

Table 2: Descriptive statistics of the data

\begin{tabular}{|l|c|c|c|c|}
\hline & $\begin{array}{c}\text { TOTAL AIR } \\
\text { MOVEMENT } \\
\text { (THOUSAND) }\end{array}$ & $\begin{array}{c}\text { TOTAL CARGO } \\
\text { MOVEMENT } \\
\text { (KILOGRAMS) }\end{array}$ & $\begin{array}{c}\text { TOTAL NUMBER } \\
\text { OF EMPLOYMENT } \\
\text { (THOUSAND) }\end{array}$ & $\begin{array}{c}\text { TOTAL PASSENGER } \\
\text { MOVEMENT } \\
\text { (MILLION) }\end{array}$ \\
\hline Mean & 224274.5385 & 149775426.9 & 22906 & 12152026.62 \\
\hline Median & 225922 & 166782990 & 23117 & 13981677 \\
\hline Maximum & 275827 & 211324605 & 25004 & 15722423 \\
\hline Minimum & 177627 & 77286904 & 20177 & 8157152 \\
\hline Std. Dev. & 33207.94558 & 48826191.47 & 1413.10415 & 3212267.529 \\
\hline Skewness & -0.058259227 & -0.302168401 & -0.28379064 & -0.326573458 \\
\hline Kurtosis & 1.581045181 & 1.421353454 & 2.29792036 & 1.269282607 \\
\hline & & & & 1.853574445 \\
\hline Jarque-Bera & 1.097963386 & 1.547730107 & 0.44149318 & 0.395823362 \\
\hline Probability & 0.577537622 & 0.461226952 & 0.80191987 & 157976346 \\
\hline & & & 297778 & 123823952136685.00 \\
\hline Sum & 2915569 & 1947080550 & 23962360.00 & 13 \\
\hline Sum Sq. Dev. & 13233211799.23 & 28607963684695100.00 & & 13 \\
\hline
\end{tabular}

A preliminary analysis was carried out on the variables to test the pattern of distribution as well as conformity to the normality assumptions. This is because many statistical analyses (especially inferential analysis) require that a distribution be normal or nearly normal (BROWN, 2016; BROWN, 2011).

Table 2 shows that the skewness (S) values of total aircraft movement, total cargo movement, total number of employees, and total passenger movement range between -0.328 and -0.058 . This result suggests that the data used are approximately symmetric around the mean because the values are between -0.5 and +0.5 (BULMER, 1979), and that distributions have long left tails because of the negative signs (IHS GLOBAL INC., 2015).

Again, the values of mean and median of the data confirms that the distributions are left-skewed, because the mean is usually less than the median in a skewed-left distribution (NEWBOLD et al., 2013). Furthermore, the Kurtosis (K) values for total aircraft movement, total cargo movement, total number of employees, 
and total passenger movement range between 1.269 and 2.297, leading to the conclusion that the distributions are platykurtic as the kurtosis values are less than three (K<3) (IHS GLOBAL INC., 2015; RENCHER, 2003).

The Jarque-Bera (JB) test was used to test the hypothesis that the samples are drawn from a normal distribution. The probabilities associated with the JarqueBera are all above 0.05 ( $p>0.05$ ). Therefore, we do not have enough statistical evidence to reject the null hypothesis that the data is normally distributed. Thus, we conclude that it is likely that the data follows a normal distribution.

\subsection{Analysis of Aircraft Movement}

Figure 2 shows the trend of aircraft movement between 2004 and 2016. It is observed that the Nigeria aviation industry has been facing challenges from years back following the continuous fluctuations as seen in the graph.

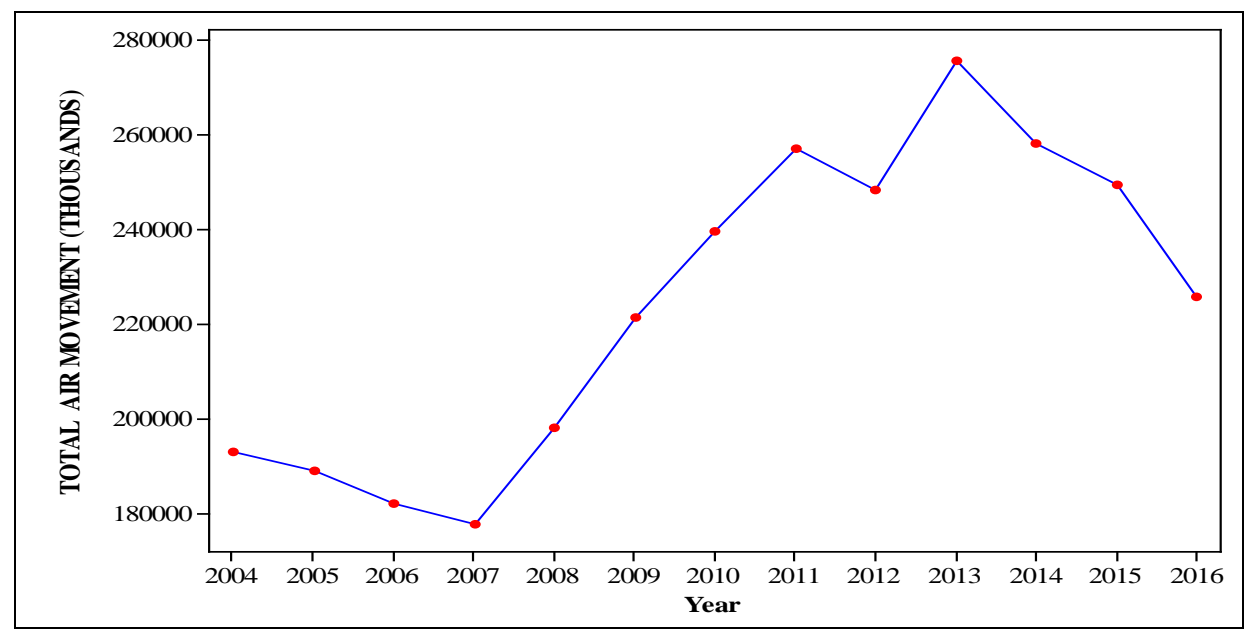

Figure 2: Aircraft Movement Between 2004 and 2016

The graph shows a steady decline in aircraft movement between 2004 and 2007. This decline in aircraft movement could be explained by the exit of Nigeria's carrier, the Nigeria Airways, from the market in 2004. The lowest dip occurred in 2007, which was the year that the concession of terminal two of the Murtala Mohammed Airport (MMA2) was granted to Bi-Courtney Aviation Service Limited (BASL) by the Government of the Federal Republic of Nigeria. An upward trend in aircraft movement is noticeable again between 2008 and 2011.

An explanation for this is that the concession of terminal two of the Murtala Mohammed Airport to Bi-Courtney Aviation Service Limited (BASL) boosted aircraft movement in the country. However, between year 2011 and 2012 there was also a slight decrease in aircraft movement, with a rebound again in 2013 , which represents 
the peak in aircraft movement. The decline from 2013 to 2016 is due to recession and inflation in the country.

In order to test $\mathrm{H}_{1}$, which states that there is a significant relationship between number of employee and aircraft throughput, a simple regression analysis was used to test for the level of significance and correlation existing between the number of employees (the independent variable) and aircraft movement (the dependent variable). The scatterplot diagram (Figure 3 ) of variables shows negative association between total air movement and total number of passengers.

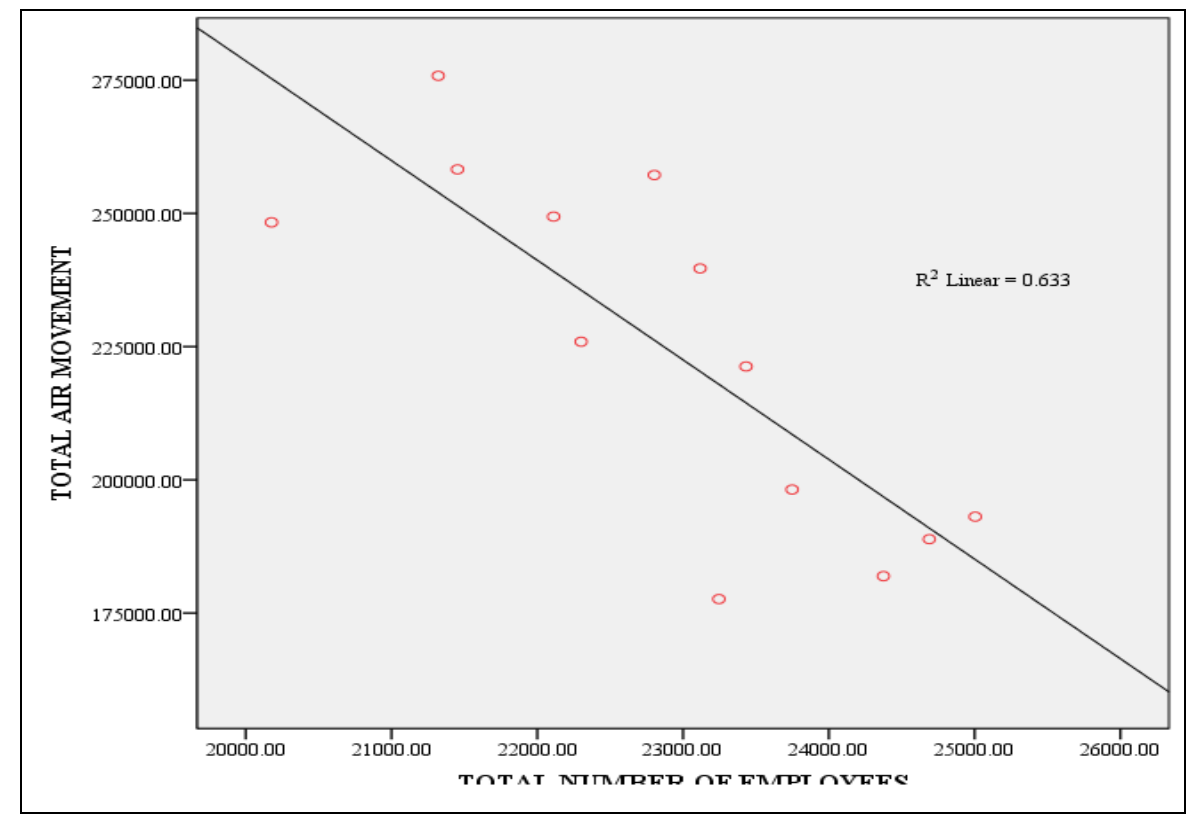

Figure 3: Scatter Plot of Total Air Movement Vs Total Number of Employees

The analysis of variance is shown in Table 3, while Table 4 contains the model summary.

From the result of the analysis of variance (ANOVA) presented in Table 4, the model significance is $F(1,11)=18.973, P=0.001$. We can conclude that the regression model statistically significantly predicts the outcome variable as the sig. (value) of 0.001 is less than alpha (0.05). We therefore accept the hypothesis that there is a significant relationship between the total number of employee and total aircraft movement.

Table 3: ANOVAa Table

\begin{tabular}{lrrrrr}
\hline Source & DF & Sum of Squares & Mean Square & F & Sig. \\
\hline Regression & 1 & $8376648545 / 121$ & 8376648545.121 & 18.973 & $0.001^{\mathrm{b}}$ \\
\hline Residual Error & 11 & 4856563254.110 & 441505750.374 & & \\
\hline Total & 12 & 13233211799.231 & & & \\
\hline
\end{tabular}

a. Dependent Variable: TOTAL AIRCRAFT MOVEMENT

b. Predictors: (Constant), TOTAL NUMBER OF EMPLOYEES 
From Table 3, Adjusted R Square value of 0.600 signifies the $60 \%$ of the variance in total aircraft throughput (response variable) can be explained by the number of employees (the predictor or explanatory varaible). An $\mathrm{R}$ value of 0.796 indicates a high degree of correlation between the dependent variable $(Y)$ and the independent variable or explanatory variable $(X)$.

Table 4: Model Summary

\begin{tabular}{|l|r|r|r|r|}
\hline Model & \multicolumn{1}{|c|}{$\mathrm{R}$} & R Square & \multicolumn{1}{c|}{ Adjusted R Square } & Std. Error of the Estimate \\
\hline 1 & $.796^{\mathrm{a}}$ & .633 & .600 & 21012.03823 \\
\hline
\end{tabular}

a. Predictors: (Constant), TOTAL NUMBER OF EMPLOYEES

Again, since we are able to get a significant value as the coefficient of the equation ( $\beta$ ), it gives a relationship between the dependent and independent variables. This implies that the higher aircraft movement operations in terms of takeoff and landing, the higher aircraft traffic services, thereby increases airport operational performance (PIUS et al., 2017).

Table 5: Regression Coefficients ${ }^{a}$

\begin{tabular}{|l|l|r|r|r|r|r|}
\hline \multicolumn{2}{|c|}{} & \multicolumn{2}{|c|}{$\begin{array}{c}\text { Unstandardized } \\
\text { Coefficients }\end{array}$} & $\begin{array}{c}\text { Standardized } \\
\text { Coefficients }\end{array}$ & \multicolumn{1}{c|}{$\mathrm{t}$} & \multicolumn{1}{c|}{ Sig. } \\
\cline { 3 - 7 } Model & \multicolumn{1}{|c|}{ B } & \multicolumn{1}{c|}{ Std. Error } & Beta & & \\
\hline \multirow{2}{*}{1} & (Constant) & 652546.467 & 98494.995 & & 6.625 & .000 \\
\cline { 2 - 7 } & $\begin{array}{l}\text { TOTAL NUMBER OF } \\
\text { EMPLOYEES }\end{array}$ & -18.697 & 4.292 & -.796 & -4.356 & .001 \\
\hline
\end{tabular}

a. Dependent Variable: TOTAL AIRCRAFT MOVEMENT

From Table 5, we predict total aircraft movement from total number of employees as follows:

$$
\text { Total aircraft movement }=652546.467-18.697 \text { (Total number of employees) } \text {. }
$$

The negative 18.697 shows that for every variable of aircraft movement predicted there will be a negative increase in the number of employee by 18.697. The $p$-value $(<0.05)$ next to the total number of employee implies that this variable is significant in explaining total aircraft movement.

\subsection{Analysis of Passenger Movement}

Figure 4 is the time series graph of passenger throughput in Nigeria from 2004 to 2016, showing a distinct fluctuation in passenger throughput in the country. It could be seen from the graph that there was limited movement between 2004 and 2008, after which passenger throughput began to increase sharply from the year up to 2011 with a passenger throughput of $14,889,820$. 
This is perhaps as a result of the concession arrangement in some of the airports. Although there was a decline in 2012, another increase was seen immediately after this up to 2014 , with up to $15,722,423$ total number of passengers moved. There was another decline in passenger throughput up to 2016, perhaps, caused by the recession in the country, which affected various airline industries, and the impact of high exchange rate on the price of aviation fuel.

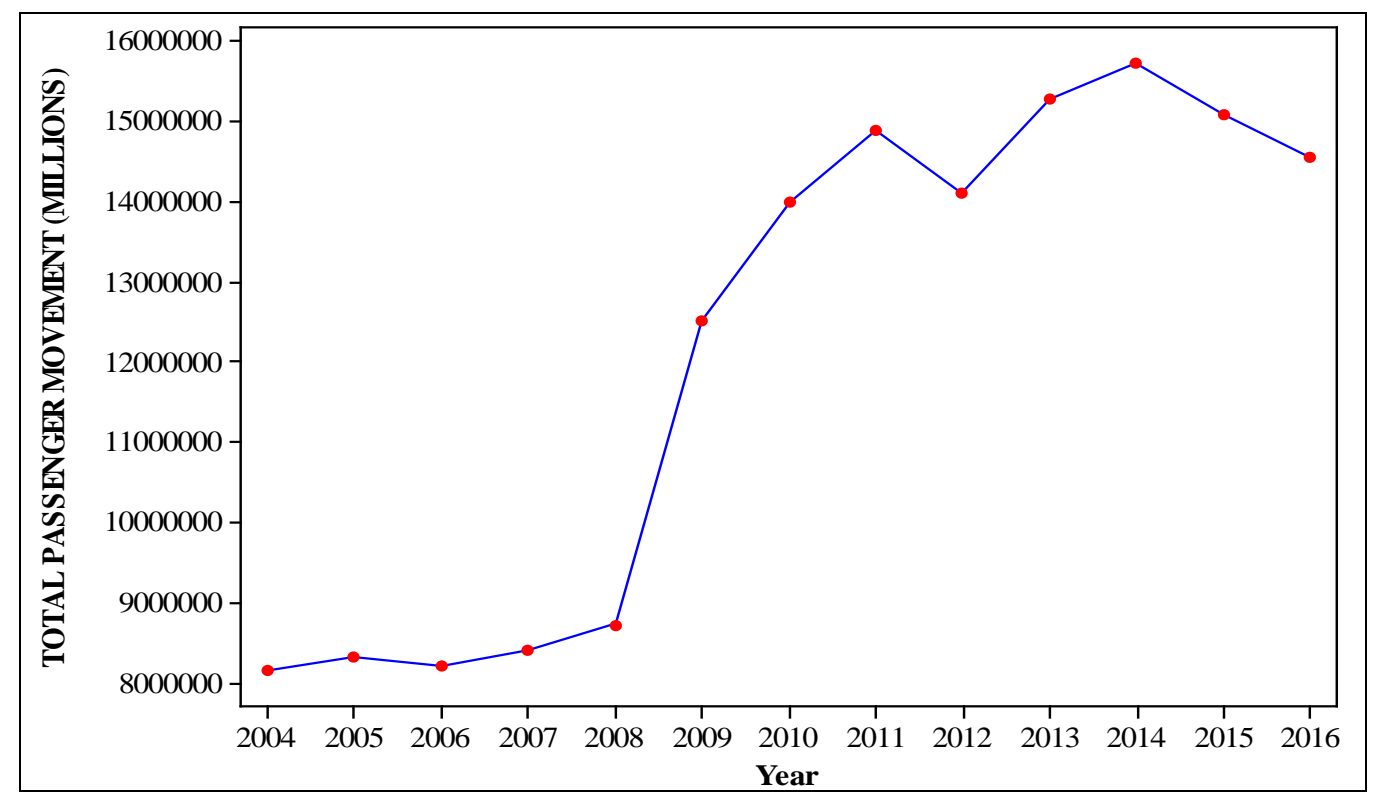

Figure 4: Passenger Throughput (2004 to 2016)

A scatter plot of total passenger movement and total number of employees (Figure 5) shows a negative association between the two variables.

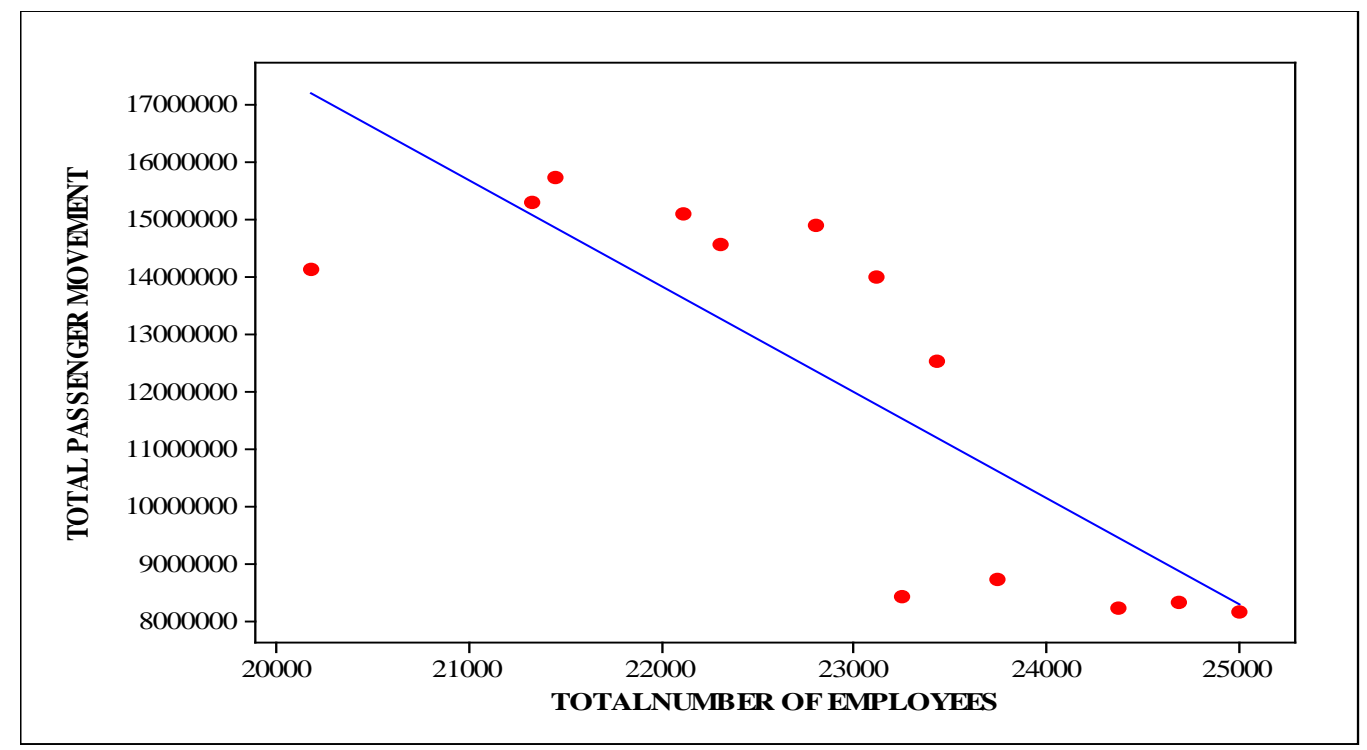

Figure 5: Total Passenger Movement vs Total Number of Employees

The analysis of variance is summarised in Table 6 , while Table 7 is the regression model summary. From the result of the analysis of variance (ANOVA) 
presented in Table 6, the model significance is $F(1,11)=21.132, P=0.001$. Hence, it can be concluded that the regression model statistically significantly predicts the outcome variable as the sig. ( ${ }^{p}$-value) of 0.001 is less than alpha (0.05). Therefore, there is enough statistcial evidence to accept the hypothesis that there is a significant relationship between the total number of employee and total passenger movement.

Table 6: ANOVA

\begin{tabular}{|c|c|c|c|c|c|c|}
\hline \multicolumn{7}{|c|}{ ANOVA $^{\mathrm{a}}$} \\
\hline \multicolumn{2}{|c|}{ Model } & Sum of Squares & $\mathrm{df}$ & Mean Square & $\mathrm{F}$ & Sig. \\
\hline \multirow{2}{*}{1} & Regression & 81433995095030.40 & 1 & 81433995095030.40 & 21.132 & $.001^{\mathrm{b}}$ \\
\cline { 2 - 8 } & Residual & 42389957041654.60 & 11 & 3853632458332.24 & & \\
\cline { 2 - 8 } & Total & 123823952136685.00 & 12 & & & \\
\hline
\end{tabular}

a. Dependent Variable: TOTAL PASSENGER MOVEMENT

b. Predictors: (Constant), TOTAL NUMBER OF EMPLOYEES

The adjusted R Square value of 0.627 implies that about $62.7 \%$ of the variance in total passenger throughput is explained by the number of employees. An $R$ value of 0.811 indicates a high degree of correlation between the dependent variable $(Y)$ and the independent variable or explanatory variable $(X)$.

Table 7: Model Summary

\begin{tabular}{|l|c|r|r|r|}
\hline Model & $\mathrm{R}$ & \multicolumn{1}{|c|}{$\mathrm{R}$ Square } & \multicolumn{1}{c|}{ Adjusted R Square } & \multicolumn{1}{c|}{ Std. Error of the Estimate } \\
\hline 1 & $.811^{\mathrm{a}}$ & .658 & .627 & 1963067.105 \\
\hline
\end{tabular}

a. Predictors: (Constant), TOTAL NUMBER OF EMPLOYEES

Table 8: Regression Coefficient

\begin{tabular}{|l|l|r|r|r|r|r|}
\hline \multicolumn{7}{|c|}{ Coefficients $^{\mathrm{a}}$} \\
\hline Model & & \multicolumn{2}{|c|}{ Unstandardized Coefficients } & \multicolumn{1}{c|}{$\begin{array}{c}\text { Standardized } \\
\text { Coefficients }\end{array}$} & $\mathrm{t}$ & Sig. \\
\hline & & \multicolumn{1}{c|}{$\mathrm{B}$} & \multicolumn{1}{c|}{ Std. Error } & \multicolumn{1}{c|}{ Beta } & & \\
\hline 1 & (Constant) & 54378745.095 & 9201976.630 & & 5.909 & .000 \\
\hline & $\begin{array}{l}\text { TOTAL NUMBER } \\
\text { OF EMPLOYEES }\end{array}$ & -1843.478 & 401.024 & -.811 & -4.597 & .001 \\
\hline
\end{tabular}

a. Dependent Variable: TOTAL PASSENGER MOVEMENT

Using the result shown in Table 8, we can predict total passenger movement from total number of employees as follows:

Total passenger movement $=54378745.095-1843.478$ (Total number of employees)

The implication of the above is that for every variable of passenger movement predicted, there will be a negative increase in the number of employee by a figure of about 1843 . The $p$-value $(<0.05)$ obtained for the total number of employee implies that this variable is significant in explaining total passenger movement. 
DOI: 10.14807/ijmp.v10i1.828

\subsection{Analysis of Cargo Movement}

The time series graph of annual cargo throughput of Nigeria air transport operation is shown in Figure 6. The graph shows continuous fluctuation of cargo throughput, with the highest decline in cargo carried occurring in 2005, before it started increasing continuously again up to 2015 when it peaked.

The positive catalyst to this gradual increase was the airport concession arrangement that came into being from 2006. Cargo movement began to experience a decline again from year 2015 till date, due to economic recession in the country.

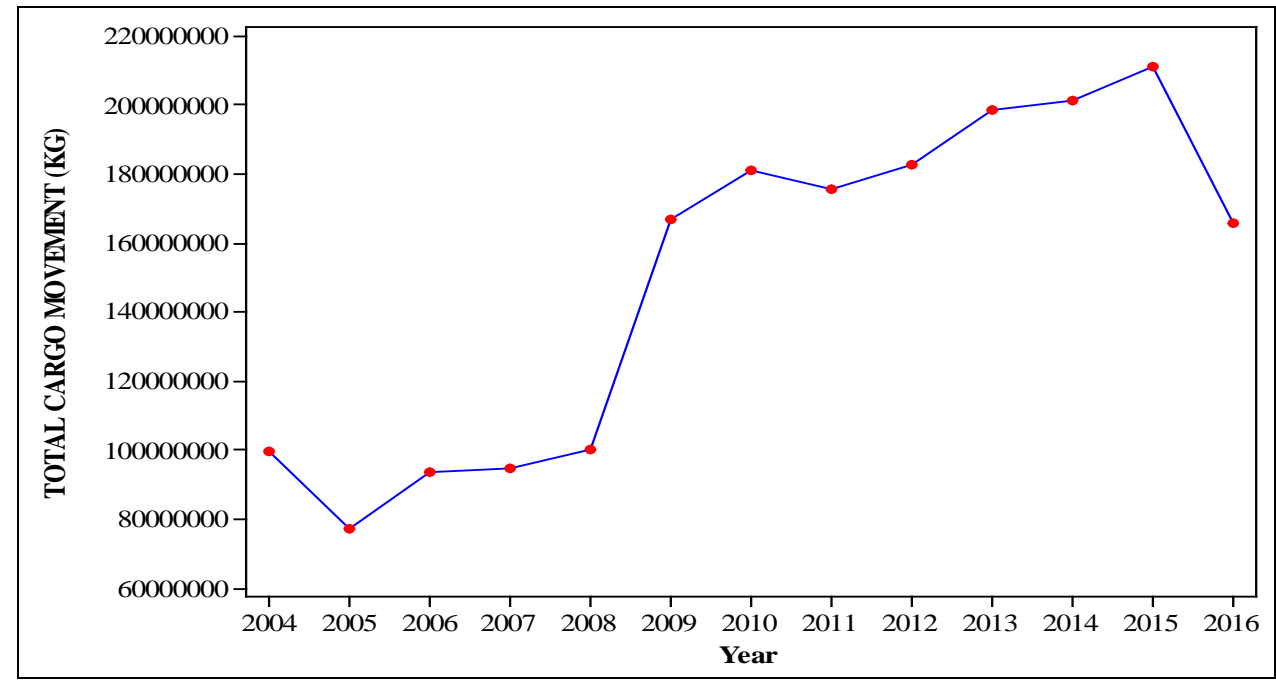

Figure 6: Cargo Throughput (2004 to 2016)

A scatter plot of total cargo movement and total number of employees (Figure 7) shows a negative association between two variables.

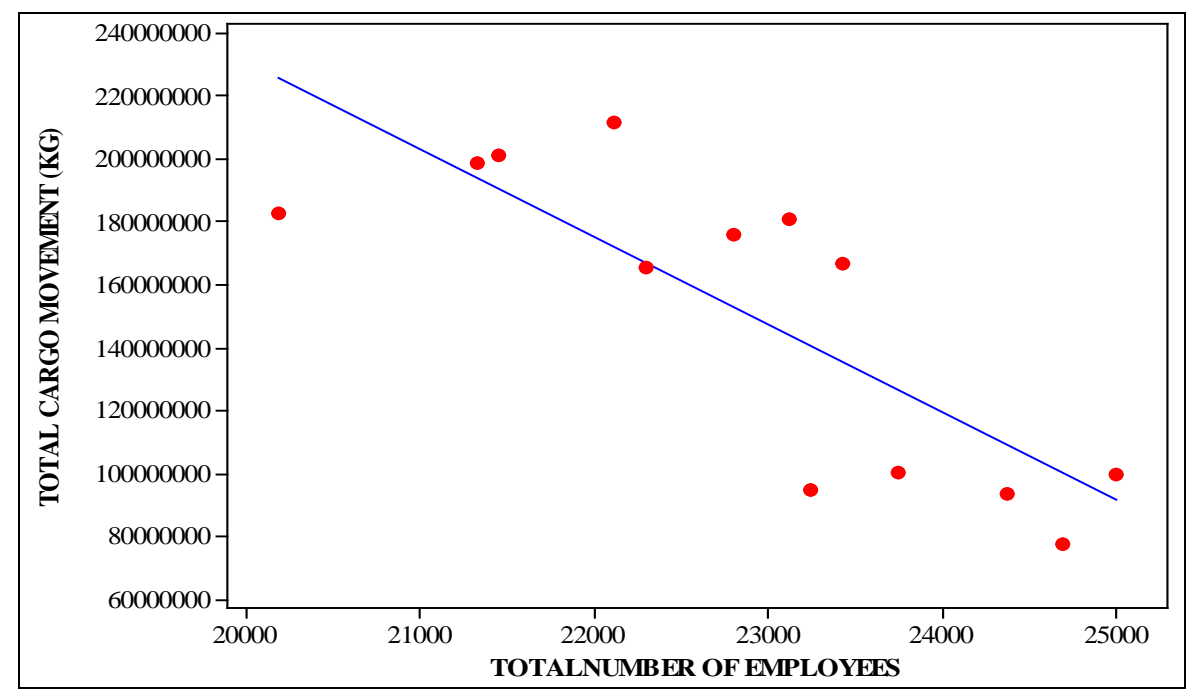

Figure 7: Scatter plot of Total Cargo Movement Vs Total Number of Employees 
The analysis of variance is presented in Table 9, while Table 10 is the regression model summary is shown. The analysis of variance (ANOVA) shown in Table 10 shows the existence of a significant relationship between cargo movement and number of employees.

The ANOVA result shown in Table 9, gives a model significance of $F(1,11)=$ 20.234, $P=0.001$. Thus, the regression model statistically significantly predicts the outcome variable as the sig. ( ${ }^{p}$-value) of 0.001 is less than alpha (0.05). This is enough statistcial evidence for us to accept the hypothesis that a significant relationship exists between the total number of employee and total passenger movement.

Table 9: ANOVA

\begin{tabular}{|l|l|l|l|l|l|l|}
\hline \multicolumn{7}{|c|}{ ANOVA $^{\mathrm{a}}$} \\
\hline Model & & Sum of Squares & df & Mean Square & F & Sig. \\
\hline 1 & Regression & 18532852220026400.00 & 1 & 18532852220026400.00 & 20.234 & $.001^{\text {b }}$ \\
\hline & Residual & 10075111464668700.00 & 11 & 915919224060791.00 & & \\
\hline & Total & 28607963684695100.00 & 12 & & & \\
\hline
\end{tabular}

The adjusted R Square value of 0.616 implies that $61.6 \%$ of the variance in the response variable (total cargo throughput) can be explained by the predictor variable (the total number of employees). An $R$ value of 0.805 indicates a high degree of correlation between the dependent variable $(Y)$ and the independent variable or explanatory variable $(X)$.

Table 10: Model Summary

\begin{tabular}{|l|l|l|l|l|}
\hline Model & $\mathrm{R}$ & $\mathrm{R}$ Square & Adjusted R Square & Std. Error of the Estimate \\
\hline 1 & $.805^{\mathrm{a}}$ & .648 & .616 & 30264157.42 \\
\hline
\end{tabular}

a. Predictors: (Constant), TOTAL NUMBER OF EMPLOYEES

Table 11: Regression Coefficient

\begin{tabular}{|l|l|l|l|l|l|l|}
\hline \multicolumn{2}{|c|}{ Coefficients $^{\mathrm{a}}$} \\
\hline \multirow{2}{*}{$\begin{array}{l}\text { Model } \\
1\end{array}$} & \multicolumn{2}{|l|}{$\begin{array}{l}\text { Unstandardized Coefficients } \\
\text { Coefficients }\end{array}$} & $\mathrm{t}$ & Sig. \\
\cline { 4 - 9 } & $\mathrm{B}$ & Std. Error & Beta & & \\
\cline { 2 - 9 } & $\begin{array}{l}\text { TOTAL NUMStant) } \\
\text { EMPLOYEES }\end{array}$ & 786799131.662 & 141864773.028 & & 5.546 & .000 \\
\hline
\end{tabular}

a. Dependent Variable: TOTAL CARGO MOVEMENT

Using the result shown in Table 11, we can predict total cargo movement from total number of employees as follows: 


\section{Total cargo movement $=786799131.662-27810.342$ (Total number of employees)}

This suggests that for every variable of cargo movement predicted there will be a negative increase in the number of employee by a figure of about 27810 . The $p$ value $(<0.05)$ obtained for the total number of employees implies that this variable is significant in explaining total cargo movement.

\section{CONCLUSION}

In conclusion, the study observed that the air transportation industry has been facing turbulence over the years, suggested by the result from air transport operation analysis which shows growth within year 2007 to 2014 notably. The result shows a growth in passenger throughput from $8,409,944$ to $15,722,423$, aircraft movement increased from 177,627 to 258,624 , and cargo throughput increased from $94,523,909 \mathrm{~kg}$ to $201,208,117 \mathrm{~kg}$.

This steady increase was as a result of concession and privatization of some airports. Furthermore, from year 2015 it was observed that there was a steady and serious decline in the level of air transport operational performance. Passenger throughput declined to $14,562,191$ in 2016 , while the cargo throughput decreased to $165,568,809 \mathrm{~kg}$, and aircraft movement experienced a significant decrease to 225,922 .

Overall, it means that Nigeria's air transport performance is sub-optimal because of the serious decline in the various output variables. Officially, Nigeria faced recession from the year 2015 resulting to an increase in the price of dollar. This increase in dollar in relation to the value of Naira has put many airlines out of business at worse or rationalisation of operations at best. The outcome of the hypothesis tested shows that number of employee has a significant relationship with aircraft throughput, passenger throughput, and cargo carried respectively.

The work has been constrained by the dearth of data on total operational cost, total assets, total check-in counters, number of gates, and terminal capacity. This greatly affected the level of statistical analysis carried out in this study. For instance, while it would have been desirable to use multiple regression (instead of simple regression analysis) to determine which variable impacts more on the response variable, this was not possible because there was only one predictor variable (TNE). 
The above limitations notwithstanding, the outcome of the study has some policy implications. For instance, in view of the significant impact of number of employees on total aircraft movement, total passenger movement as well as total cargo movement, the Federal Airports Authority of Nigeria (FAAN), Nigerian Airspace Management Agency (NAMA), Nigerian Civil Aviation Authority (NCAA) and the operating airlines should be staffed with adequately motivated staff in order to ensure and maintain optimal performance. Furthermore, based on the commendable performance attributable to the concession arrangement in some of the airports, there is need for divestment of government interest in these airports in order to enhance performance.

\section{REFERENCES}

ACZEL, A. D.; SOUNDERPANDIAN, J. (2009) Complete Business Statistics, USA, McGraw-Hill Primis.

AHMAD, S.; SCHROEDER, R. G. (2003) The impact of human resource management practices on operational performance: recognizing country and industry differences. Journal of operations Management, n. 21, p. 19-43.

ANDERSON, D. R.; SWEENEY, D. J.; WILLIAMS, T. A.; CAMM, J. D.; COCHRAN, J. J. (2015) Essentials of Statistics for Business and Economics, USA, Cengage Learning.

ANFOFUM, A. A.; SAHEED, S. Z.; ILUNO, C. (2015) Air Transportation Development and Economic Growth in Nigeria. Journal of Economics and Sustainable Development, n. 6, p. 1-11.

BALTACI, N.; SEKMEN, O.; AKBULUT, G. (2015) The Relationship between Air Transport and Economic Growth in Turkey: Cross-Regional Panel Data Analysis Approach. Journal of Economics and Behavioral Studies, n. 7, p. 89.

BERENSON, M. L.; LEVINE, D. M.; KREHBIEL, T. C. (2012) Basic Business Statistics: Concepts and Applications, New Jersey, Prentice Hall.

BON, A. T.; MUSTAFA, E. M. A. (2013) Impact of Total Quality Management on Innovation in Service Organizations: Literature Review and New Conceptual Framework. Procedia Engineering, n. 53, p. 516-529.

BOSEDE, A.; ABALABA, B.; AFOLABI, D. (2013) Transport Infrastructure Improvement and Economic Growth in Nigeria. International Journal of Humanities and Social Science Invention, n. 2, p. 23-31.

BROWN, S. (2011) Measures of Shape: Skewness and Kurtosis. MATH200 Statistics. New York, USA: Tompkins Cortland Community College/The State University of New York.

BROWN, S. (2016) Measures of Shape: Skewness and Kurtosis [Online]. Available: https://brownmath.com/stat/shape.htm [Accessed 5 May 2018].

BULMER, M. G. (1979) Principles of Statistics, Dover. 
CROCKATT, M. A. (2000) Airport Infrastructure and Regional Development: A Case for Resurrecting the Growth Pole Concept. Master of Arts Thesis, University of Manitoba.

DHARMAWAN, I. G. N. I. (2012) The effect of air transport to economic development in Indonesia, Erasmus University.

DOGANIS, R. (2005) The Airport Business, London, Routledge.

EASTERLY, W.; REBELO, S. (1993) Fiscal policy and economic growth. Journal of monetary economics, n. 32, p. 417-458.

FEDERAL AVIATION ADMINISTRATION. Airport Categories [Online]. Washington, DC: United States Department of Transportation. Available: https://www.faa.gov/airports/planning_capacity/passenger_allcargo_stats/categories/ [Accessed 17 March 2018].

GILLEN, D.; LALL, A. (2001) Non-parametric measures of efficiency of US airports. International Journal of Transport Economics/Rivista internazionale di economia dei trasporti, p. 283-306.

IHS GLOBAL INC. (2015) EViews 9 User's Guide I, Irvine CA, USA, IHS Global Inc. ISHUTKINA, M.; HANSMAN, R. J. (2008) Analysis of Interaction between Air Transportation and Economic Activity. The 26th Congress of ICAS and 8th AIAA ATIO. 8888.

JARŽEMSKIENÉ, I. (2012) Applying the method of measuring airport productivity in the Baltic region. Transport, n. 27, p. 178-186.

JUAN, E. J. (1995) Airport infrastructure: the emerging role of the private sector, recent experiences based on 10 case studies. CFS Discussion Paper Series (No. CFS 115). Washington, DC: World Bank.

JUAN, E. J. (2001) Financing Air Navigation Infrastructure in Emerging Markets. Air Finance, Fall.

KAYDOS, W. (1998) Operational Performance Measurement: Increasing Total Productivity, Boca Raton, Florida, CRC Press.

KELLER, G. (2014) Statistics for Management and Economics, Boston, USA, Cengage Learning.

MINITAB BLOG EDITOR. (2013) Multiple Regression Analysis: Use Adjusted RSquared and Predicted R-Squared to Include the Correct Number of Variables [Online]. Pennsylvania: Minitab Inc. Available: http://blog.minitab.com/blog/adventures-in-statistics-2/multiple-regession-analysisuse-adjusted-r-squared-and-predicted-r-squared-to-include-the-correct-number-ofvariables [Accessed 5 May 2018].

NEWBOLD, P.; CARLSON, W. L.; THORNE, B. M. (2013) Statistics for Business and Economics (Global Edition), Harlow, England, Pearson Education Limited.

NIGERIAN NATIONAL PETROLEUM CORPORATION. (2016) Nigeria Profile [Online]. Abuja, Nigeria: Nigerian National Petroleum Corporation. Available: http://www.nnpcgroup.com/NNPCBusiness/BusinessInformation/OilGasinNigeria/Nig eriaProfile.aspx [Accessed 17 April 2018]. 
NWAOGBE, O. R.; OGWUDE, I. C.; IBE, C. C. (2017a) Efficiency Analysis of the Nigerian Airports: An Application of DEA-BCC Model. International Scientific Journal of Air Transport Industry (AERO-Journal), n. 2, p. 28-39.

NWAOGBE, O. R.; PIUS, A.; IDOKO, F. W. (2017b) Estimating Nigerian Airports Production Functions Using Cobb Douglas Analytical Model. International Scientific Journal of Air Transport Industry (AERO-Journal), n. 2, p. 40-45.

OAKLAND, J. S. (1995) Total Quality Management: The Route To Improving Performance, Oxford; Boston, Butterworth-Heinemann.

OAKLAND, J. S. (2003) Total Quality Management: Text with Cases, ButterworthHeinemann.

OGWUDE, I. C.; NWAOGBE, O. R.; PIUS, A.; EJEM, E. A.; IDOKO, F. O. (2018) Performance Appraisal of Nigerian Airports: Stochastic Frontier Analysis. Transport \& Logistics: The International Journal, n. 18, p. 1-14.

OWEN, W. (1987) Transportation and world development, Baltimore, Maryland, U.S.A, Johns Hopkins University Press.

OXFORD ECONOMIC FORECASTING (2003) The contribution of air transport to sustainable development in Africa. Unpublished Final Report for the Air Transport Action Group. Geneva, Switzerland: Air Transport Action Group.

PABEDINSKAITÉ, A.; AKSTINAITÉ, V. (2014) Evaluation of the airport service quality. Procedia-Social and Behavioral Sciences, n. 110, p. 398-409.

PIUS, A.; NWAOGBE, O.; AKERELE, O.; MASUKU, S. (2017a) An Appraisal of Airport Terminal Performance: Evidence from Murtala Muhammed International Airport (MMIA). International Journal of Professional Aviation Training \& Testing Research, n. 9.

PIUS, A.; NWAOGBE, O.; IDOKO, F. W. (2017) Estimation of Nigerian Airports' Production Functions: An Application of Cobb Douglas Model. In: KAZDA, A.; SMOJVER, I., eds. 6th International Conference on Air Transport (INAIR 2017): Air Transport Growth- What are the Limits?, 14-16 November 2017 2017b Prague, Czech Republic. Elsevier Procedia, 225.

RENCHER, A. C. (2003) Methods of Multivariate Analysis, New York, Wiley.

SALVATORE, D.; REAGLE, D. (2002) Statistics and Econometrics, New York, McGraw-Hill.

SARKIS, J. (2000) An analysis of the operational efficiency of major airports in the United States. Journal of Operations management, n. 18, p. 335-351.

STEPHENS, M. S.; UKPERE, W. I. (2011) Airport capacity utilization in Nigeria: A performance and efficiency analysis. African Journal of Business Management, $n$. 5, p. 11104.

SUTIA, S.; SUDARMA, M.; ROFIATY, D. (2013) The Influence of Human Capital Investment, Leadership and Strategic orientation on Airport Performance. International Journal if Business and Management Invention, n. 2, p. 26-32.

TABACHNICK, B. G.; FIDELL, L. S. (2013) Using Multivariate Statistics, New Jersey, Pearson Education, Inc. 
TERZIOVSKI, M. (2006) Quality management practices and their relationship with customer satisfaction and productivity improvement. Management Research News, n. 29, p. 414-424.

TSENG, K.; HO, J.-F.; LIU, Y.-J. (2008) A study on the performance evaluation of major international airports in the world. Journal of Modelling in Management, $n$. 3, p. 71-81.

UGBOAJA, P. C. (2013) A Sustainability Assesment of Nigerian Transport Policy. International Journal of Asian social science, n. 3, p. 1208-1226.

WANKE, P.; BARROS, C.; NWAOGBE, O. R. (2016) Assessing productive efficiency in Nigerian airports using Fuzzy-DEA. Transport Policy, n. 49, p. 9-19.

WEISS, N. A. (2012) Introductory Statistics, Boston, Addison-Wesley.

WORLD BANK (1996) Sustainable transport: priorities for policy reform. Washington, D.C.: The International Bank for Reconstruction and Deelopment/The World Bank.

ZHANG, B.; WANG, J.; LIU, C.; ZHAO, Y. (2012) Evaluating the technical efficiency of Chinese airport airside activities. Journal of Air Transport Management, n. 20, p. 23-27. 